\title{
Rapid Monitoring of Copper Over a Wide Concentration range by High-Sensitive Potentiometric Membrane Electrode Based on 1-cyano-1-piperidino-2(N-piperidino methyl)-cyclo hexane
}

\author{
Leila Hajiaghababaei, ${ }^{1 *}$ Iman Borbor, ${ }^{1}$ Jamshid Najafpour, ${ }^{1}$ Mohammad Raouf Darvich, ${ }^{1}$ \\ Mohammad Reza Ganjali ${ }^{2}$ and Fateme Dehghan ${ }^{1}$ \\ 1 Department of Chemistry, Islamic Azad University, Yadegar-e-Imam Khomeini (RAH) Shahre Rey Branch, Tehran, Iran. \\ 2 Center of Excellence in Electrochemistry, Faculty of Chemistry, University of Tehran, Tehran, Iran. \\ * Corresponding Author; Postal Address: Department of Chemistry, Faculty of Science, Islamic Azad University \\ of Yadegar-e-Imam Khomeini (RAH) Shahre Rey, Km. 5, Tehran- Ghome freeway, Tehran, Iran. \\ Phone: +98 9125017614, Fax: +98 21 33999022, lhajiaghababaei@yahoo.com
}

Received December 3 ${ }^{\text {rd }}, 2015$; Accepted April 27 ${ }^{\text {th }}, 2016$.

\begin{abstract}
In this paper, 1-cyano-1-piperidino-2(N- piperidino methyl)-cyclohexane was synthesized. The lowest-energy conformer of this molecule (Ligand) with axial and equatorial forms of cyanide toward cyclohexane and local minima corresponding to their complexes with various ions were obtained using Monte Carlo procedure by Molecular Mechanics with MMFF94 method. The calculated results of the Gibbs free energy of the reaction using density functional theory (DFT) show that the thermodynamic reactivity of complexation of copper ion with studied ligand is the best. Finally, a selective and sensitive copper-ion selective liquid membrane electrode for potentiometric monitoring of ultra-trace amounts of $\mathrm{Cu}^{2+}$ was prepared by using 1-cyano-1-piperidino-2(N-piperidino methyl)-cyclohexane as an excellent ionophore. This electrode exhibits a Nernstian response for $\mathrm{Cu}^{2+}$ ions over a concentration range $\left(1.5 \times 10^{-2}\right.$ to $\left.1.0 \times 10^{-8} \mathrm{~mol} \mathrm{~L}^{-1}\right)$ with a slope of $28.4 \pm 0.4 \mathrm{mV}$ per decade. The limit of detection of the sensor is $6.3 \times$ $10^{-9} \mathrm{~mol} \mathrm{~L}^{-1}$. The sensor has a relatively fast response time $(<10 \mathrm{~s})$ and a useful working $\mathrm{pH}$ range of 5.0-8.5. Interference of some cations was also evaluated. The practical utility of the $\mathrm{Cu}^{2+}$ ion sensor has been demonstrated by using it as an indicator electrode in potentiometric titration of $\mathrm{Cu}^{2+}$ with EDTA and for direct determination of $\mathrm{Cu}^{2+}$ in well water samples.
\end{abstract}

Key words: Copper Monitoring; Liquid Membrane Electrode; Potentiometric; 1-cyano-1-piperidino-2(N-piperidino methyl)-cyclohexane.

\section{Introduction}

Heavy metal ion contamination represents a significant threat to the ecosystem. Among them, copper is an essential element at the trace level for hemoglobin formation, carbohydrate metabolism, catecholamine biosynthesis and proper functioning of many important enzyme systems [1,2], but the intake of large quantities can be toxic. When levels of $\mathrm{Cu}$ exceed certain values, defense mechanisms to protect against excess $\mathrm{Cu}$ are overcome and toxicity results. The reported list of toxic $\mathrm{Cu}$ species often includes $\mathrm{Cu}(\mathrm{OH})^{+}, \mathrm{Cu}_{2}(\mathrm{OH})_{2}{ }^{2+}$, and $\mathrm{CuCO}_{3}$. However, without doubt, $\mathrm{Cu}^{2+}$ ions that are present in various aqueous solutions are considered to be the most toxic of dissolved
Resumen. En este trabajo se sintetizó el compuesto 1-ciano-1-piperidin-2(N- piperidin metil)-ciclohexano. Usando Mecánica Molecular con el método MMFF94 y el procedimiento Monte Carlo, se obtuvo el confórmero de mínima energía para esta molécula (ligante) con arreglos axial y ecuatorial de cianida respecto a ciclohexano, así como los mínimos locales. Los resultados de energías libres de Gibbs de reacción, calculados usando la teoría de funcionales de la densidad (TFD) muestran que la reactividad termodinámica de la complejación de cobre iónico con el ligante estudiado es la mejor. Finalmente, se preparó un electrodo de membrana selectivo y sensible a iones cobre para monitorear potenciométricamente cantidades de ultra-traza de $\mathrm{Cu}^{2+}$. Para ello se usó 1-ciano-1-piperidin-2(N-piperidin metil)-ciclohexano como excelente ionósforo. Este electrodo exhibe una respuesta Nernstian para iones $\mathrm{Cu}^{2+}$ en un rango de concentraciones $\left(1.5 \times 10^{-2}\right.$ to $1.0 \times 10^{-8} \mathrm{~mol} \mathrm{~L}^{-1}$ ) con pendiente de $28.4 \pm 0.4 \mathrm{mV}$ por década. El límite de detección del sensor es $6.3 \times 10^{-9} \mathrm{~mol} \mathrm{~L}^{-1}$. El sensor tiene una respuesta relativamente rápida $(<10 \mathrm{~s})$ y un rango de $\mathrm{pH}$ de trabajo útil de 5.0-8.5. También se evaluó la interferencia de otros cationes. La utilidad práctica del sensor de iones $\mathrm{Cu}^{2+}$ ha sido demostrada usándolo como un electrodo indicador en la valoración potenciométrica de $\mathrm{Cu}^{2+}$ con EDTA y para la determinación directa de $\mathrm{Cu}^{2+}$ en muestras de agua. Palabras clave: monitoreo de cobre; electrodo de membrana líquida; potenciométrico; 1-ciano-1-piperidin-2(N- piperidin metil)-ciclohexano.

copper species [3]. $\mathrm{Cu}^{2+}$ is known to catalysis lipid peroxidation (please correct), possibility forming free radicals. Thus, the determination of $\mathrm{Cu}^{2+}$ in water samples is important with due attention to (synonym may apply) the narrow window of concentration between essentially and toxicity.

Over recent years, development of novel sensors for the detection of heavy metals has increased because of the importance of controlling the level of environmental pollutants in various samples. Regarding to, an extensive effort has been explained in the synthesis and characterization of various carriers to develop new sensors for the determination of various ions, in different real samples [4-17]. The advantages of ion selective electrodes (ISEs) including accuracy, portability, sensitivity 
Leila Hajiaghababaei et al.

and selectivity, low cost and ease of use have led to the development and application of some ISEs based on the application of different ionophores, for the determination of $\mathrm{Cu}^{2+}$ ions. Several $\mathrm{Cu}^{2+}$ sensors have been developed based on various ionophore such as Cefazoline [18], Schiff base [19], salens [20], benzothiazol derivative[21], hydroxybenzylide thiosemicarbazide[22]. However, these efforts have not been very fruitful as the developed electrodes have either one, two or, in some cases all of the following problems: (1) high detection limit, (2) a narrow working concentration range, and (3) serious interferences from others ions and (4) short life time. In continuation of our previous works on developing new ion-selective potentionmetric sensors [23-30], in the present work we synthesized 1-cyano-1-piperidino-2(N- piperidino methyl)-cyclohexane (CPNPMC) and the various theoretical thermodynamic properties (such as enthalpy, entropy and Gibbs free energy) of the reaction complexation of $\mathrm{Mg}^{2+}, \mathrm{Cu}^{2+}, \mathrm{Zn}^{2+}, \mathrm{Ag}^{+}, \mathrm{Cd}^{2+}$ and $\mathrm{Pb}^{2+}$ ions with CPNPMC molecule are studied with B3LYP/6-31G(d) computational level for all atoms except $\mathrm{Ag}^{+}, \mathrm{Cd}^{2+}$ and $\mathrm{Pb}^{2+}$ ions where B3LYP/LANL2DZ computational level are used. Finally, we introduced a sensitive copper-ion selective liquid membrane electrode for potentiometric monitoring of copper concentration over a wide range in environmental samples by using CPNPMC as an excellent ionophore.

\section{Experimental Section}

\section{Apparatus}

The FT-IR spectra were recorded on a Bruker, Tensor 27 instrument using $\mathrm{KBr}$ disks. ${ }^{1} \mathrm{H}$ and ${ }^{13} \mathrm{C}$ NMR spectra were recorded with a Bruker Avance DRX-500 instrument using $\left(\mathrm{CD}_{3}\right)_{2} \mathrm{SO}$ as the deuterated solvent containing tetramethylsilane as internal standard, at 500 and $75 \mathrm{MHz}$, respectively, in parts per million, and $J$ in hertz. Mass spectra were obtained with a Finnigan-MAT-8430 Electron impact ionization-mass spectrometer $(70 \mathrm{eV})($ in $\mathrm{m} / \mathrm{z})$.

A Corning ion analyzer $250 \mathrm{pH} / \mathrm{mV}$ meters was used for the potential measurements at $25.0 \pm 0.1{ }^{\circ} \mathrm{C}$. Two $\mathrm{Ag} / \mathrm{AgCl}$ reference electrodes (Azar-Electrode, Iran) were used as the internal and external reference electrodes.

\section{Reagents and Materials}

Reagent grade dibutyl phthalate (DBP), high relative molecular weight polyvinyl chloride (PVC), sodium tetraphenyl borate (NaTPB) and tetrahydrofurane (THF) were purchased from Merck and used as received. 2-(N- piperidino methyl) cyclohexanone was synthesized according to Mannich reaction [31] as described elsewhere [26]. Piperidinium chloride, hydrochloric acid, potassium cyanide were purchased from Merck. Nitrate salts of the cations used (from Merck and Aldrich) were all of the highest purity available, and used without any further purification except for vacuum drying over $\mathrm{P}_{2} \mathrm{O}_{5}$. Doubly distilled deionized water was used throughout.

\section{Synthesis of Ionophore}

The 1-cyano-1-piperidino-2(N- piperidino methyl)-cyclohexane (Fig. 1) was synthesized as follows:

$0.94 \mathrm{~g}$ ( $7.7 \mathrm{mmol})$ of piperidinium chloride salt was poured in a $250 \mathrm{ml}$ flask. Then, $10 \mathrm{ml}$ distilled water was added. $1.0 \mathrm{~g}$ $(5.1 \mathrm{mmol})$ of 2-(N-piperidino methyl) cyclohexanone was added under stirring the mixture. Then, $3 \mathrm{ml}$ of ethanol and $5 \mathrm{ml}$ hydrochloric acid $10 \%$ were added. Finally, $1.01 \mathrm{~g}(15.5 \mathrm{mmol})$ of potassium cyanide powder which had been solved (Previously dissolved) in $8 \mathrm{ml}$ distilled water was added in drop-wise manner and rapid stirring. The reaction mixture was stirred for $72 \mathrm{~h}$ at $25^{\circ} \mathrm{C}$. The end of reaction was distinguished by thin layer chromatography (TLC) method. After three times extraction by diethylether in alkaline medium and drying over dehydrated sodium sulfate, $0.82 \mathrm{~g}$ (yield $51.2 \%$ ) solid product was obtained. Pure 1-cyano-1-piperidino-2(N- piperidino methyl)-cyclohexane was obtained by recrystallization from the mixture n-hexane/ethyl acetate (3/1). The schematic representation of reaction is shown in Fig. 1. (m.p. $\left.66-67^{\circ} \mathrm{C}\right) .\left(\mathrm{R}_{\mathrm{f}}=\right.$ 0.34). IR $\left(\mathrm{KBr} \mathrm{cm}^{-1}\right): 2939.73 ; 2854.22 ; 2221.65 ; 1473.53$; $1445.28 ; 1382.42 ; 1282.67 ; 1202.84 ; 1128.18 ; 1075.52$; 1038.48; 993.63; 993.44; 893.17; 861.65; 777.95. ${ }^{1} \mathrm{H}$ NMR: $\left(\mathrm{CDCl}_{3}\right) \delta \mathrm{ppm}, 1.57-1.72(4 \mathrm{H}, \mathrm{m}) ; 1.75-1.78(9 \mathrm{H}, \mathrm{m}) ; 1.80-$ $1.82(8 \mathrm{H}, \mathrm{m}) ; 2.13-2.15$ (4H, m); 2.34-2.35 (2H, m); 2.37-2.38 $(2 \mathrm{H}, \mathrm{m}) ; 2.54-2.71\left(2 \mathrm{H}, \mathrm{dd} . \mathrm{CH}_{2}\right.$ diastereotopie, between piperidino and cyclohexane ring). ${ }^{13} \mathrm{C}$ NMR: $\left(\mathrm{CDCl}_{3}\right) \delta \mathrm{ppm}, 22.83$, 23.73, 24.68, 25.36, 26.91, 37.56, 63.21, 41.42, 54.76, 75.87; 121.07 (Please check NMR spectra and try to assign some representative signals in $1 \mathrm{H}$. In $13 \mathrm{C}$ there are less signals than expected). MS: m/e( relative intensity): 55(46.15); 50(38.46);

82(30.76); 84(52.30); [98(100) $\mathrm{CH} 2={ }^{+} \mathrm{N}$ ]; 99(38.46); 122(9.23); 142(7.69); 165(35.38); 179(23.07); 205(27.69); 232(24.61); 248(27.70); 275(18.46); [289(27.71) $\left.\mathrm{M}^{+}\right] ; \mathrm{M}^{+1}(12.61) ; \mathrm{M}^{+2}(9.30)$.

\section{Methods and Computations}

We obtained the equilibrium geometry of 1-cyano-1-piperidino-2(N- piperidino methyl)-cyclohexane molecule (Ligand) with axial and equatorial forms of cyanide toward cyclohexane (Fig. 2) and local minima corresponding to their complexes with $\mathrm{Mg}^{2+}, \mathrm{Cu}^{2+}, \mathrm{Zn}^{2+}, \mathrm{Ag}^{+}, \mathrm{Cd}^{2+}$ and $\mathrm{Pb}^{2+}$ ions (Fig. 3) by Molecular Mechanics in the gas phase performed using MMFF94 method [32]. Then the equilibrium conformer procedure using Monte Carlo method is used to replace the initial conformer of a molecule by the lowest-energy conformer. The equilibrium conformer procedure using Monte Carlo method attempt to characterize the conformers available to a molecule based on exhaustive conformational search for finding the lowest energy conformations.

This procedure is typically used to get a good guess at the best (lowest-energy) conformer for calculation of properties using quantum chemical methods. 


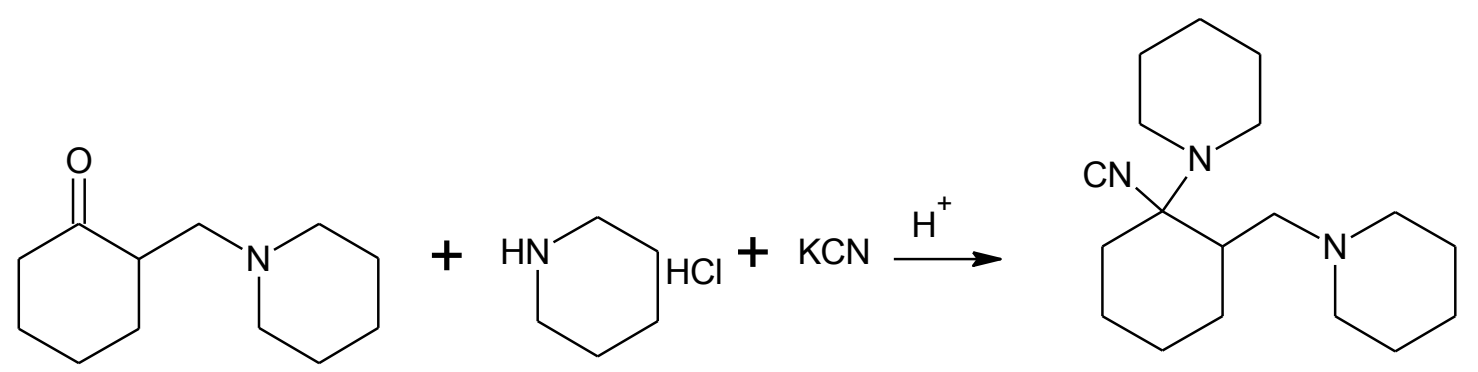

Fig. 1. The Schematic illustration of synthesis of 1-cyano-1-piperidino-2(N-piperidino methyl)-cyclohexane (CPNPMC).

The density functional theory (DFT) with the exchange-correlation potential that constructed from Becke's three parameter functional for exchange (B3) $[33,34]$ along with the Lee-YangParr parameterization for correlation (LYP) [35] was employed for optimization of 1-cyano-1-piperidino-2(N-piperidino methyl)-cyclohexane molecule and their complexes with $\mathrm{Mg}^{2+}, \mathrm{Cu}^{2+}, \mathrm{Zn}^{2+}, \mathrm{Ag}^{+}, \mathrm{Cd}^{2+}$ and $\mathrm{Pb}^{2+}$ ions. These calculations are performed by6-31G(d) basis set for all atoms except $\mathrm{Ag}^{+}, \mathrm{Cd}^{2+}$ and $\mathrm{Pb}^{2+}$ ions where LANL2DZ (Los Alamos National Laboratory of Double Zeta) basis set are used. The frequencies were computed to assess thermodynamic properties molecules at the same theoretical level and ensure the nature of local minima.

All DFT calculations in the gas phase were performed using Spartan'10 software [36].

\section{Electrode Preparation}

The general procedure to prepare the PVC membrane was as followed: Different amounts of the ionophore (CPNPMC) along with appropriate amounts of additive were weighed.
Then, known amounts of PVC and plasticizer were added to the mixture. The mixture was dissolved in $2 \mathrm{~mL}$ of tetrahydrofuran (THF), and the solution was mixed well. The resulting mixture was transferred into a glass dish of $2 \mathrm{~cm}$ diameter. The solvent was evaporated slowly until an oily concentrated mixture was obtained. A Pyrex tube (3-5 mm o.d.) was dipped into the mixture for about $5 \mathrm{~s}$ so that a transparent membrane of about $0.3 \mathrm{~mm}$ thickness was formed. The tube was then pulled out from the mixture and kept at room temperature for about $24 \mathrm{~h}$. The tube was then filled with an internal filling solution $\left(1.0 \times 10^{-3} \mathrm{~mol} \mathrm{~L}^{-1} \mathrm{Cu}\left(\mathrm{NO}_{3}\right)_{2}\right)$. The electrode was finally conditioned for $24 \mathrm{~h}$ by soaking in a $1.0 \times 10^{-3} \mathrm{~mol} \mathrm{~L}^{-1} \mathrm{Cu}\left(\mathrm{NO}_{3}\right)_{2}$ solution.

\section{Emf Measurements}

The following cell was assembled for the conduction of the emf (electromotive force) measurements; $\mathrm{Ag}-\mathrm{AgCl}, \mathrm{KCl}$ (satd.) | internal solution, $1.0 \times 10^{-3} \mathrm{~mol} \mathrm{~L}^{-1} \mathrm{Cu}\left(\mathrm{NO}_{3}\right)_{2} \mid$ PVC membrane | sample solution $\mid \mathrm{Ag}-\mathrm{AgCl}, \mathrm{KC1}$ (satd.)
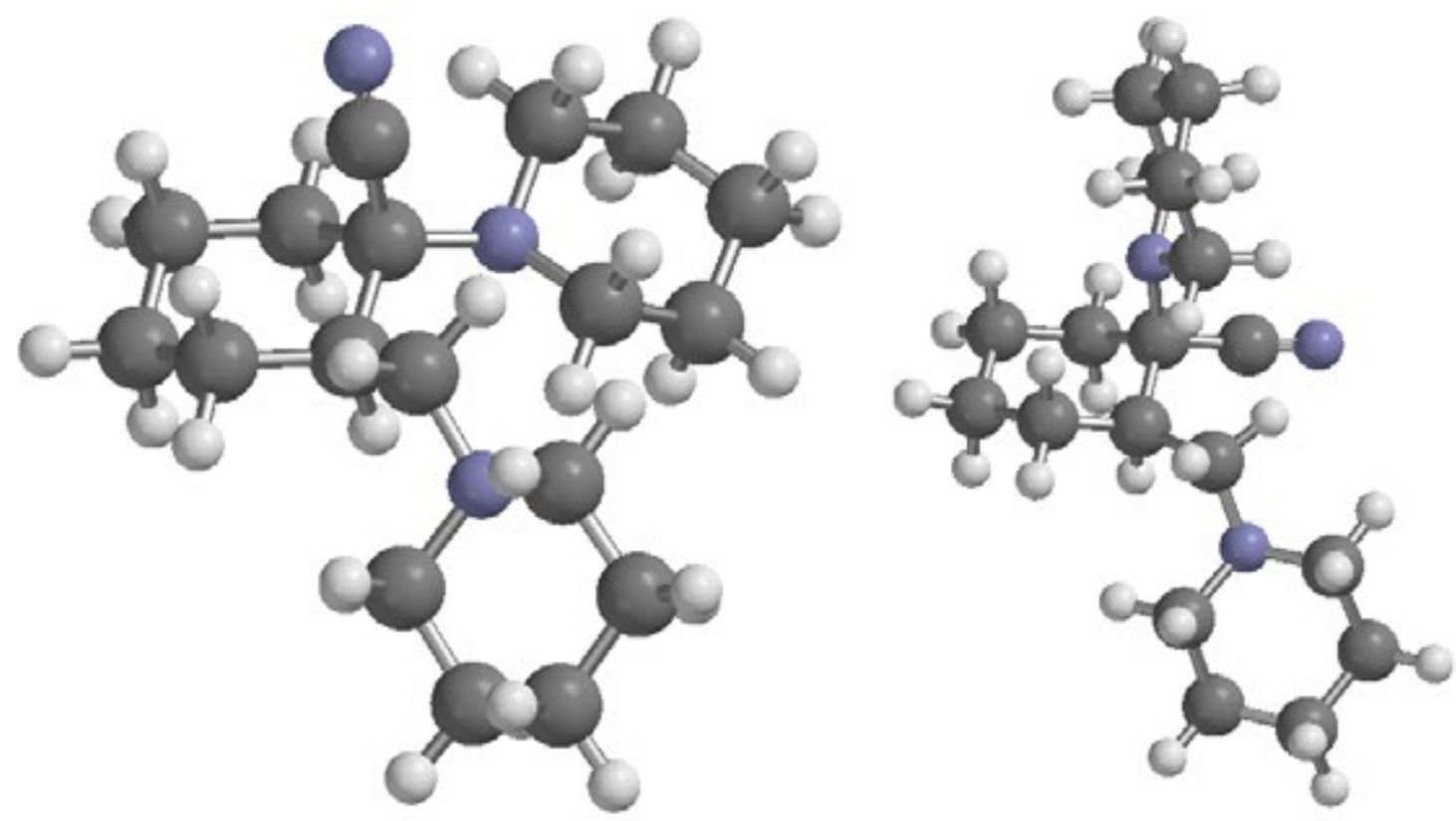

Fig. 2. 1-cyano-1-piperidino-2(N- piperidino methyl)-cyclohexane molecule with axial (left) and equatorial (right) forms. 

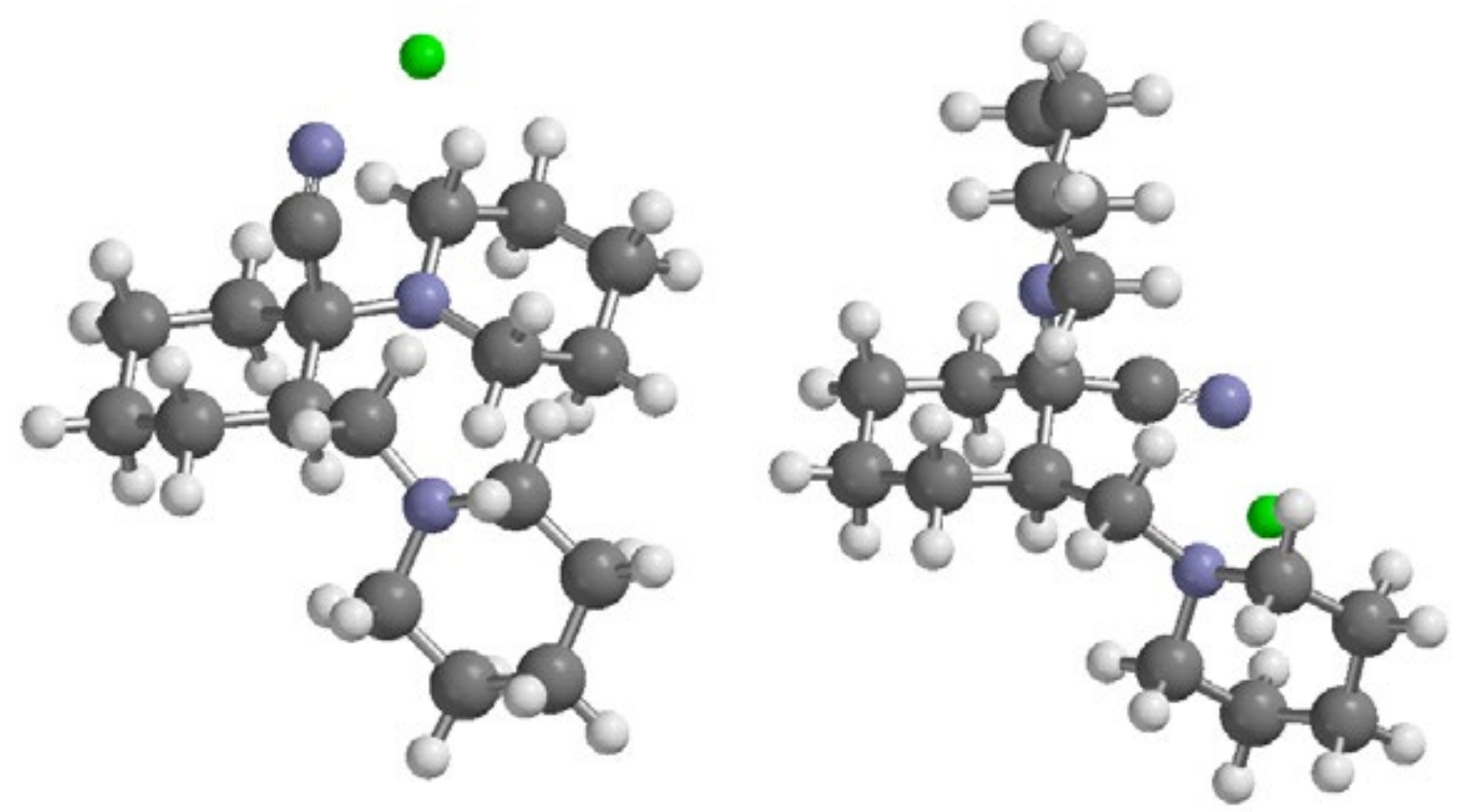

Fig. 3. Complex of ion metals (for example: $\mathrm{Zn}^{2+}$ ) with 1-cyano-1-piperidino-2(N-piperidino methyl)-cyclohexane ligand with axial (left) and equatorial (right) forms.

These measurements were preceded using calibration of the electrodes with several standard solutions. Activities were calculated according to the Debye-Huckel procedure.

\section{Results and Discussion}

\section{Theoretical results}

The calculations were done for each of the reactants (Ligands and Ion metals) and products (Complexes) in the reaction where the axial and equatorial forms of cyanide in ligand bonded to ion metals:

$$
\text { Ligand }+ \text { Ion metal } \rightarrow \text { Complex }
$$

In this study, it is assumed that after metal ions penetrate the membrane, only interacted with ligand, and metal ions interactions with other organic materials are poor. Therefore, all calculations were performed in the gas phase. Distances of ion metals to nitrogen atoms of ligand in result complexes (as

Table 1. Distances of ion metals with nitrogen atoms of ligand in result complexes by B3LYP method.

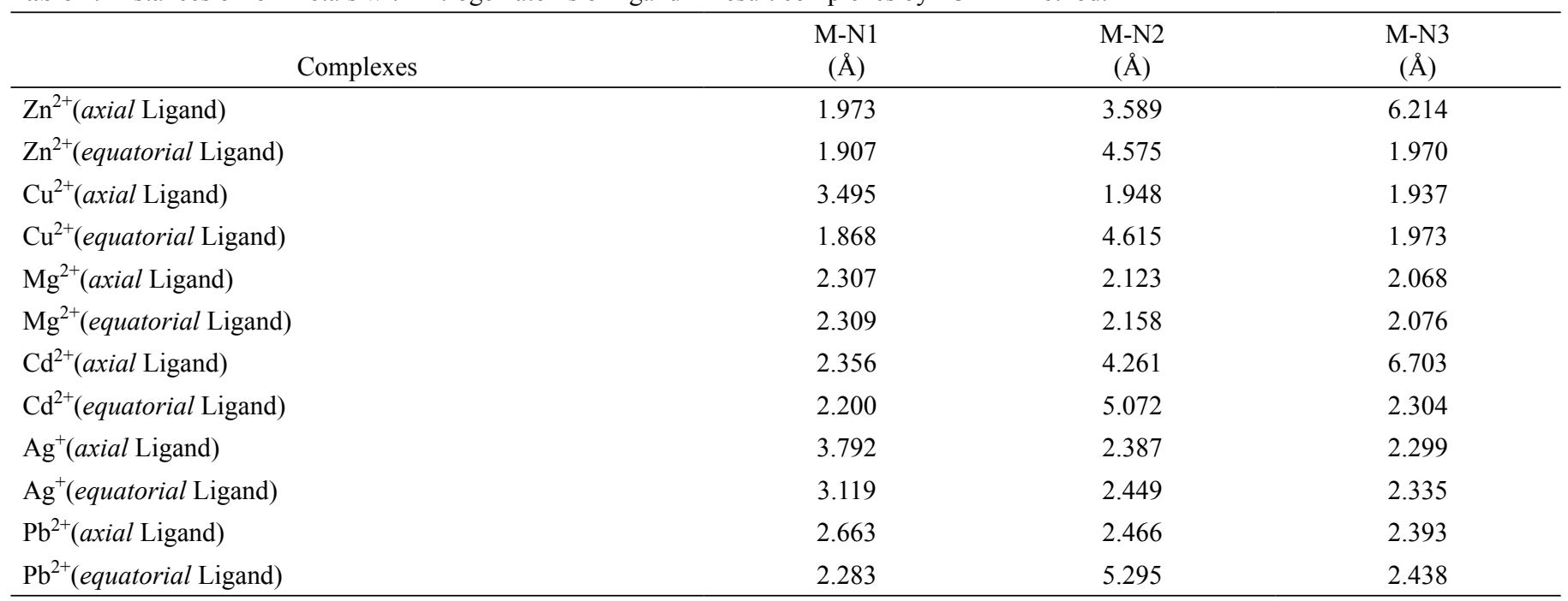

M: Ion metal; N1: Nitrogen atom in cyanide group; N2: Nitrogen atom in 1-piperidine group N3: Nitrogen atom in 2(N- piperidino methyl) group. 
Table 2. Calculated thermo chemistry values for the reaction: Ligand + Ion metal $\rightarrow$ Complex by B3LYP method.

\begin{tabular}{|c|c|c|c|c|c|}
\hline Complexes & $\begin{array}{c}\Delta \varepsilon_{\mathrm{o}} \\
(\mathrm{kJ} / \mathrm{mol})\end{array}$ & $\begin{array}{c}\Delta \mathrm{H}_{\mathrm{th}} \\
(\mathrm{kJ} / \mathrm{mol})\end{array}$ & $\begin{array}{c}\Delta \mathrm{S}_{\mathrm{th}} \\
(\mathrm{kJ} / \mathrm{mol} \mathrm{K})\end{array}$ & $\begin{array}{c}\Delta \mathrm{G}_{\mathrm{th}} \\
(\mathrm{kJ} / \mathrm{mol})\end{array}$ & $\begin{array}{c}\Delta \mathrm{G}_{0} \\
(\mathrm{~kJ} / \mathrm{mol})\end{array}$ \\
\hline $\mathrm{Zn}^{2+}$ (axial Ligand) & -997.199 & -7.733 & -140.967 & 34.297 & -962.902 \\
\hline $\mathrm{Zn}^{2+}$ (equatorial Ligand) & -1179.648 & -3.280 & -146.484 & 40.394 & -1139.254 \\
\hline $\mathrm{Cu}^{2+}$ (axial Ligand) & -1397.215 & 0.979 & -149.891 & 45.669 & -1351.546 \\
\hline $\mathrm{Cu}^{2+}$ (equatorial Ligand) & -1340.866 & -4.346 & -142.979 & 38.283 & -1302.584 \\
\hline $\mathrm{Mg}^{2+}$ (axial Ligand) & -989.858 & 0.699 & -140.473 & 42.581 & -947.277 \\
\hline $\mathrm{Cd}^{2+}($ axial Ligand $)$ & -785.387 & -7.920 & -138.356 & 33.331 & -752.056 \\
\hline $\mathrm{Cd}^{2+}$ (equatorial Ligand) & -871.818 & -5.076 & -146.993 & 38.750 & -833.068 \\
\hline $\mathrm{Ag}^{+}$(axial Ligand) & -329.022 & 1.923 & -149.027 & 46.356 & -282.667 \\
\hline $\mathrm{Ag}^{+}$(equatorial Ligand) & -314.144 & 2.722 & -149.015 & 47.151 & -266.993 \\
\hline $\mathrm{Pb}^{2+}$ (axial Ligand) & -790.205 & 2.432 & -152.719 & 47.966 & -742.239 \\
\hline
\end{tabular}

shown for $\mathrm{Zn}^{2+}$ with axial and equatorial forms of cyanide in Ligand in Fig. 3) are tabulated in Table 1. The results are shown that $\mathrm{Zn}^{2+}$ ion has the shortest distance with nitrogen atom in cyanide group of ligand. Also the thermo chemistry output is summarized in Table 2.

In this table, $\Delta \varepsilon_{\mathrm{o}}$ is variation of total electronic energy; $\Delta \mathrm{H}_{\mathrm{th}}, \Delta \mathrm{S}_{\mathrm{th}}$ and $\Delta \mathrm{G}_{\mathrm{th}}$ are variation of thermal corrections to the enthalpy, entropy and Gibbs free energy, respectively and $\Delta \mathrm{G}_{0}$ is Gibbs free energy of above reaction at standard state $(298 \mathrm{~K}$ and $1 \mathrm{~atm}$ ). For calculating the thermal correction of Gibbs free energy we have to add the entropy term to thermal correction of enthalpy $\left(\Delta \mathrm{G}_{\mathrm{th}}=\Delta \mathrm{H}_{\mathrm{th}}-\mathrm{T} \Delta \mathrm{S}_{\mathrm{th}}\right)$. Also Gibbs free energy is equal with summation of the variation of the total electronic energy in the reaction and thermal correction of the Gibbs free energy $\left(\Delta \mathrm{G}_{0}=\Delta \varepsilon_{\mathrm{o}}+\Delta \mathrm{H}_{\mathrm{th}}-\mathrm{T} \Delta \mathrm{S}_{\mathrm{th}}\right)$.

The variations of thermal correction to entropy complexes formation from all of ion metals with ligand are negative, so the aforementioned reaction the entropy of complexation due to aggregation in complex is inappropriate, but the enthalpy of the reaction at standard state $\left(\Delta \mathrm{H}_{0}=\Delta \varepsilon_{\mathrm{o}}+\Delta \mathrm{H}_{\mathrm{th}}\right)$ is appropriate to obtain a complex from ligand and ion metal, because the enthalpy of the reaction complexes formation from all of ion metals with ligand at standard state are negative. Therefore the results of the Gibbs free energy of the reaction show that the thermodynamic reactivity of complexation of ion metals with studied ligand are: $\mathrm{Cu}^{2+}>\mathrm{Zn}^{2+}>\mathrm{Mg}^{2+}>\mathrm{Cd}^{2+}>\mathrm{Pb}^{2+}>\mathrm{Ag}^{+}$ respectively. Also the reactivity of the axial and equatorial forms of ligand separately with each ion metal based on results in Table 1 is almost comparable.

\section{Membrane Composition Effect on the Potential Response of the Sensor}

The selectivity obtained for a sensor depends on the nature of the ionophore and membrane ingredients [37,38]. In this study, different membrane compositions, as shown in Table 3, were tested. The potential of different prepared membrane sensors was measured as function of copper ion free concentration. The linear range and slope of the potential response plots have been evaluated and given in Table 3. As can be seen, the membrane

Table 3. The optimization of the membrane ingredients.

\begin{tabular}{|c|c|c|c|c|c|c|}
\hline \multirow[b]{2}{*}{ Membrane No. } & \multicolumn{4}{|c|}{ Composition (\%) } & \multirow[b]{2}{*}{$\begin{array}{c}\text { Slope } \\
\text { (mV per decade) }\end{array}$} & \multirow[b]{2}{*}{ Linear range (M) } \\
\hline & $\begin{array}{c}\text { PVC } \\
(\% \text { wt. })\end{array}$ & $\begin{array}{c}\text { DBP } \\
(\% w t .)\end{array}$ & $\begin{array}{c}\text { Ionophore } \\
\text { (\%wt.) }\end{array}$ & $\begin{array}{l}\text { NaTPB } \\
\text { (\%wt.) }\end{array}$ & & \\
\hline 1 & 33 & 65 & $\begin{array}{ll}--- \\
\end{array}$ & 2 & $2.3 \pm 0.3$ & $1.0 \times 10^{-1}-1.0 \times 10^{-8}$ \\
\hline 2 & 30 & 63 & 5 & 2 & $5.1 \pm 0.4$ & $1.0 \times 10^{-1}-1.0 \times 10^{-8}$ \\
\hline 3 & 32 & 60 & 6 & 2 & $5.7 \pm 0.3$ & $1.0 \times 10^{-1}-1.0 \times 10^{-8}$ \\
\hline 4 & 31 & 59 & 6 & 4 & $5.4 \pm 0.4$ & $1.0 \times 10^{-1}-1.0 \times 10^{-8}$ \\
\hline 6 & 30 & 58 & 10 & 2 & $24.1 \pm 0.3$ & $1.0 \times 10^{-1}-1.0 \times 10^{-8}$ \\
\hline 7 & 31 & 55 & 12 & 2 & $27.3 \pm 0.3$ & $1.0 \times 10^{-1}-1.0 \times 10^{-8}$ \\
\hline 8 & 31 & 55 & 12 & 2 & $28.4 \pm 0.4$ & $1.5 \times 10^{-2}-1.0 \times 10^{-8}$ \\
\hline 9 & 33 & 55 & 12 & --- & $25.1 \pm 0.3$ & $1.5 \times 10^{-1}-1.0 \times 10^{-8}$ \\
\hline
\end{tabular}


with the composition of $31 \%$ PVC, $12 \%$ ionophore, $2 \%$ NaTPB and 55\% DBP (no. 8) which shows the best Nernstian slope (28.4 $\pm 0.4 \mathrm{mV} /$ decade) was the optimum one in the development of this sensor. Explain why it is the optimum.

$\mathrm{The} \mathrm{Cu}^{2+}$ ion extraction into the liquid membrane is a result of the high concentration of the ligand in the membrane. From Table 3, it was obvious that in the absence of ionophore (no. 1), the response of the recommended electrode was too low (slope of $2.3 \pm 0.3 \mathrm{mV}$ per decade) which show significant effect of the ionophore. The sensitivity of the electrode response increases with increasing ionophore content until a value of $12 \%$ is reached. It shows the affinity of the CPNPMC toward $\mathrm{Cu}^{2+}$ ion.

The second factor which helps the extraction of the $\mathrm{Cu}^{2+}$ ion is plasticizer. Plasticizer acts as a membrane solvent allowing homogeneous dissolution and diffusional mobility of the ion-pair inside the membrane. The plasticizer should be waterimmiscible liquid of low vapor-pressure, compatible with PVC and no functional groups which can undergo protonation reactions. The selectivity of such electrode can be significantly influenced by the choice of the membrane solvent. Nature of the plasticizer has a noticeable effect on analytical responses e.g. slope, linear domain and selectivity of PVC membrane electrodes [39-41]. Here, dibutyl phthalate (DBP with DC of 6.4) was chosen to be employed in the sensor construction, because plasticizers with higher dielectric constant values than DBP, leading to extraction of the polar interfering ions, which may have negative effects on the selectivity behavior of the sensor. This may seem to lead to the poorer extraction of $\mathrm{Cu}^{2+}$ ions, which have a high charge density, by the average polar solvent. But this seemed to be compensated by the selective complexation of CPNPMC with the $\mathrm{Cu}^{2+}$ ions.

The presence of lipophilic anions in a cation-selective membrane was also considered. Actually, the presence of such anions in a cation-selective membrane, which is based on a neutral carrier, decreases the ohmic resistance and improves the response behavior and selectivity. Furthermore, when the extraction capability is poor, it increases the membrane electrode sensitivity $[42,43]$. The data given in table 2 revealed that
NaTPB addition of $2 \%$ as an additive led to the slope increase of the potential sensor response from the sub-Nernstian value of $25.1 \pm 0.3 \mathrm{mV}$ per decade (no. 9) to the Nernstian value of $28.4 \pm 0.4 \mathrm{mV}$ per decade (no. 8). Addition of ionic additive to the membrane composition has improved the slope. In fact, it helps to the ion-exchange of the analyte from aqueous solution to organic layer of the membrane. But, difference between the sensitivity of proposed electrode in the absence of additive (consider to eliminate this wordand in present of additive is not marked and it shows that the extraction capability is sufficient.

\section{pH Effect on the Electrode Response}

The influence of the $\mathrm{pH}$ of the test solution on the potential response of $\mathrm{Cu}^{2+}$ ion sensor investigated at $1.0 \times 10^{-6} \mathrm{M} \mathrm{Cu}^{2+}$ solution, in the $\mathrm{pH}$ range of 2.0 up to 11 . The $\mathrm{pH}$ of the solution was adjusted by the addition of hydrochloric acid or sodium hydroxide. The resulting data is shown in Fig. 4. As can be seen, the potentials remained constant from the $\mathrm{pH}$ range 5.0 to 8.5 for this sensor. Beyond this range, relatively noteworthy fluctuations in potential were observed. The variations in potentials above the $\mathrm{pH}$ value of 8.5 might be justified by the formation of the $\mathrm{Cu}^{2+}$ ion hydroxy complexes in the solution. On the other hand, the fluctuations below the $\mathrm{pH}$ value of 5.0 were attributed to the partial protonation of the employed ionophore [44].

This ionophore has $\mathrm{N}$ atom which is intermediate donor atom and relatively soft. Therefore, charge-dipole interaction between $\mathrm{Cu}^{2+}$ ions and nitrogen atoms of ionophore is stronger than interaction between $\mathrm{H}^{+}$ions and nitrogen atoms. If $\mathrm{H}^{+}$concentration is increased, then $\mathrm{H}^{+}$ions can compete with $\mathrm{Cu}^{2+}$ ions for making complex with ionophore. In below $\mathrm{pH}$ of $5, \mathrm{H}^{+}$ concentration is enough to overcome on $\mathrm{Cu}^{2+}$ and employed ionophore can be protonated. Above $8.5 \mathrm{pH}$ values lead to the formation of $\mathrm{Cu}(\mathrm{OH})^{+}$or $\mathrm{Cu}(\mathrm{OH})_{2}$, lowering the concentration of the free $\mathrm{Cu}^{2+}$. Therefore, the $\mathrm{pH}$ range 5.0 to 8.5 was taken as the working $\mathrm{pH}$ range of the sensor.

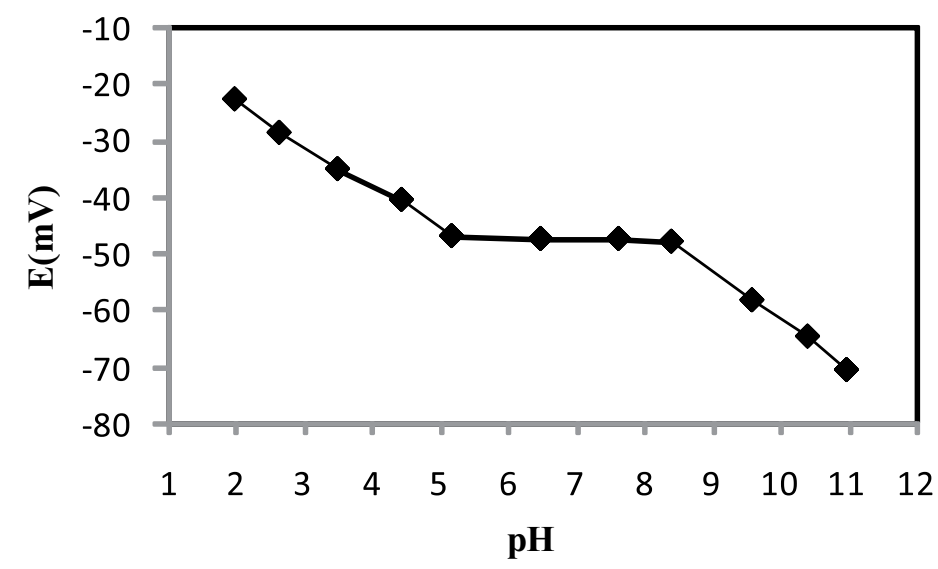

Fig. 4. Effect of $\mathrm{pH}$ on potential response of the copper ion electrode. 


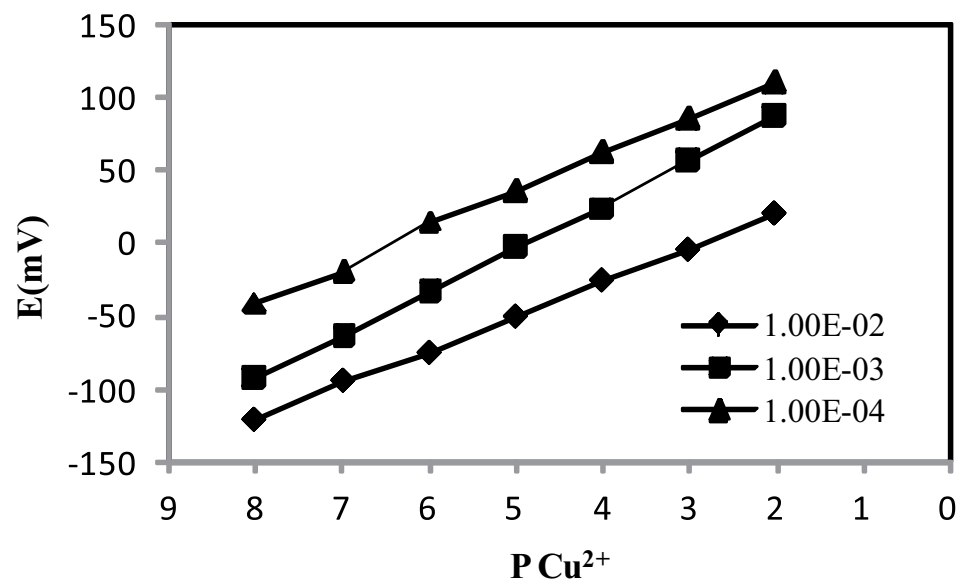

Fig. 5. The effect of internal reference solution concentration on the electrode response.

\section{Internal Solution}

Three solution of $\left(\mathrm{Cu}\left(\mathrm{NO}_{3}\right)_{2}\right)$ with different concentration $\left(1.0 \times 10^{-2}, 1.0 \times 10^{-3}\right.$ and $\left.1.0 \times 10^{-4} \mathrm{M}\right)$ was used as internal solution of the electrode and the potential response of the $\mathrm{Cu}^{2+}$ ion selective electrode was obtained (Fig. 5). It was found that the variation of concentration of the internal solution does not cause any significant differences in potential response, except for an expected change in the intercept of the resulting Nernstian plot. A $1.0 \times 10^{-3} \mathrm{M}$ concentration $\mathrm{Cu}\left(\mathrm{NO}_{3}\right)_{2}$ solution is quite appropriate for smooth functioning of the electrode system.

\section{Response Time}

The response time of an electrode is evaluated by measuring the average time required to achieve a potential within $\pm 0.1 \mathrm{mV}$ of the final steady-state potential, upon successive immersion of a series of interested ions, each having a ten-fold difference in concentration. It is notable that the experimental conditions-like the stirring or flow rate, the ionic concentration and composition of the test solution, the concentration and composition of the solution to which the electrode was exposed before experiment measurements were performed, any previous usages or preconditioning of the electrode, and the testing temperature have an effort on the experimental response time of a sensor [45].

In this work, dynamic response time was obtained by changing the $\mathrm{Cu}^{2+}$ concentration in solution, over a concentration range $1.0 \times 10^{-8}$ to $1.0 \times 10^{-2} \mathrm{M}$. The actual potential versus time traces is shown in Fig. 6 . As can be seen, in whole concentration range the electrode reaches its equilibrium response in a relatively short time $(5-10 \mathrm{~s})$. This is most probably due to the fast exchange kinetics of complexation-decomplexation of $\mathrm{Cu}^{2+}$ ion with the ionophore at the test solution-membrane interface.

\section{Measuring Range and Detection Limit}

The measuring range of an ion-selective electrode includes the linear part of the calibration graph as shown in Fig. 7. The applicable measuring range of the proposed sensor is between $1 \times 10^{-8}$ and $1.5 \times 10^{-2} \mathrm{M}$.

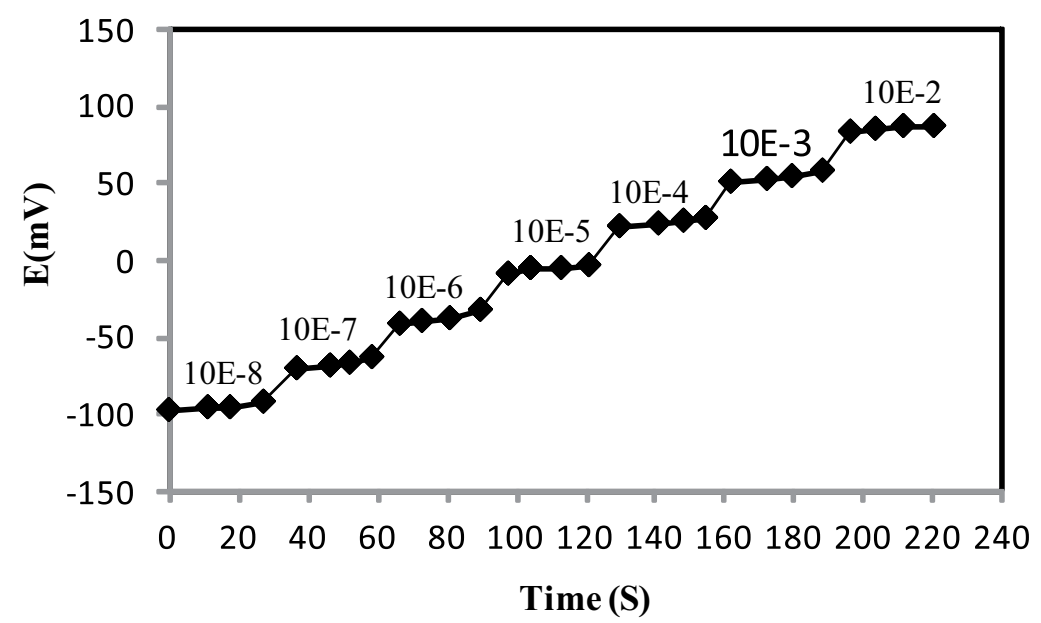

Fig. 6. Dynamic response of copper ion electrode for step changes in concentration of $\mathrm{Cu}^{2+}$. 
Table 4. The selectivity coefficients of various interfering cations for the membrane.

\begin{tabular}{ll}
\hline Ion & $\mathrm{K}_{\mathrm{MPM}}$ \\
\hline $\mathrm{Na}^{+}$ & $1.0 \times 10^{-3}$ \\
$\mathrm{Ca}^{2+}$ & $1.1 \times 10^{-3}$ \\
$\mathrm{Co}^{2+}$ & $1.4 \times 10^{-3}$ \\
$\mathrm{Cr}^{3+}$ & $2.5 \times 10^{-3}$ \\
$\mathrm{Mn}^{2+}$ & $1.6 \times 10^{-3}$ \\
$\mathrm{Ni}^{2+}$ & $1.2 \times 10^{-3}$ \\
$\mathrm{~Pb}^{2+}$ & $1.3 \times 10^{-2}$ \\
$\mathrm{Cd}^{2+}$ & $1.6 \times 10^{-2}$ \\
$\mathrm{Zn}^{2+}$ & $0.1 \times 10^{-2}$ \\
$\mathrm{Ag}^{+}$ & $0.1 \times 10^{-2}$ \\
\hline
\end{tabular}

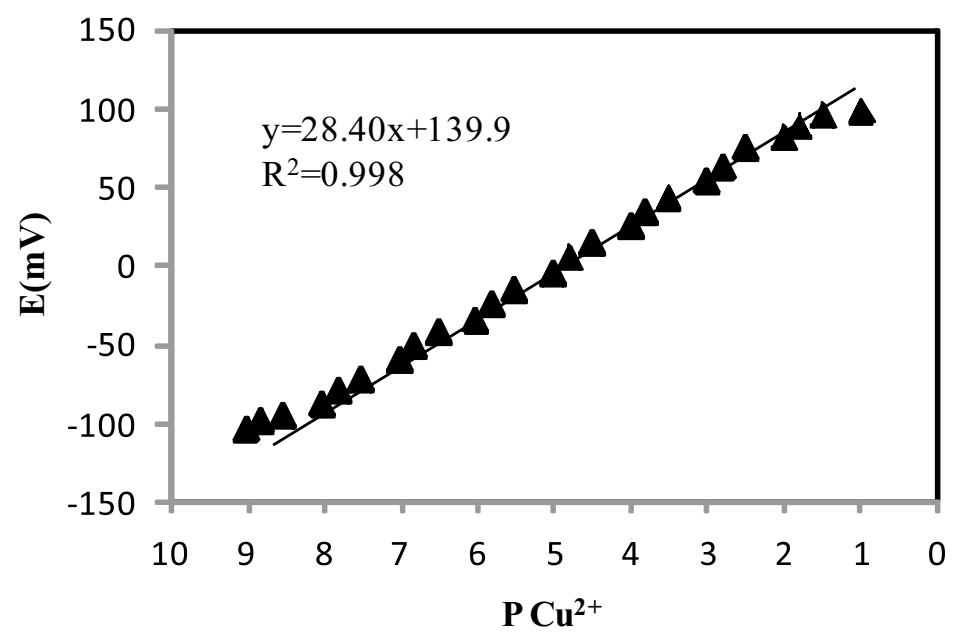

Fig. 7. The calibration curve of the $\mathrm{Cu}^{2+}$ membrane electrode.

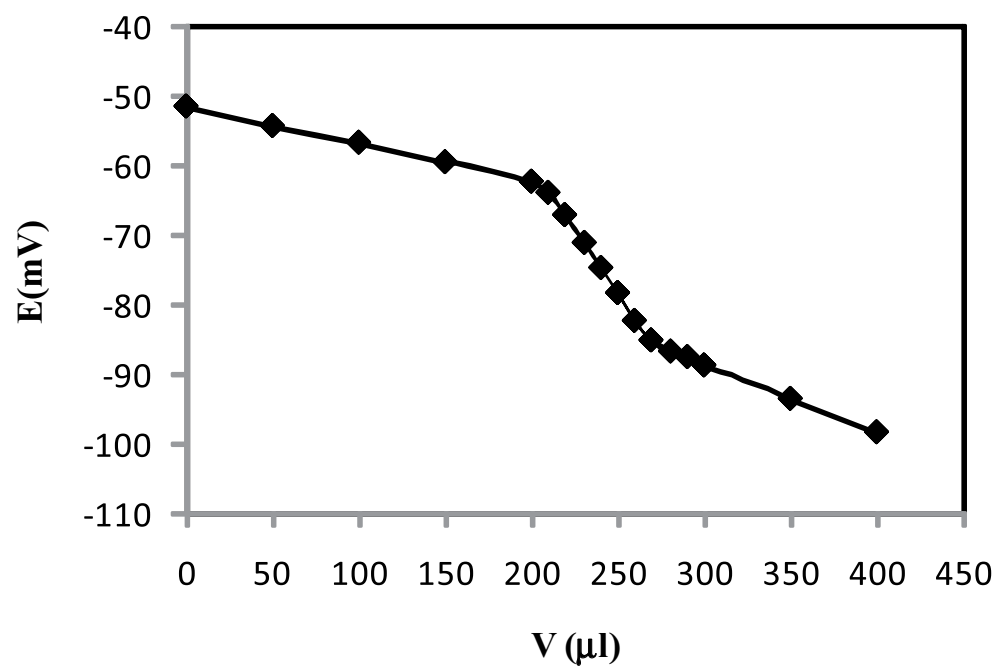

Fig. 8. Potentiometric titration curve of $1.0 \times 10^{-6} \mathrm{M} \mathrm{Cu}^{2+}$ solution with $1.0 \times 10^{-4} \mathrm{M}$ EDTA using the proposed sensor as an indicator electrode. 
Table 5. Determination results of $\mathrm{Cu}^{2+}$ ions in various samples.

\begin{tabular}{ccc}
\hline Sample & added amount $\left(\mathrm{mol} \mathrm{L}^{-1}\right)$ & Measured with proposed sensor $\left(\mathrm{mol} \mathrm{L}{ }^{-1}\right)$ \\
\hline Well water & 0 & $2.6 \times 10^{-4}( \pm 3.1) \mathrm{a}$ \\
Well water & $5.0 \times 10^{-3}$ & $5.3 \times 10^{-3}( \pm 3.5)$ \\
Well water & $1.0 \times 10^{-2}$ & $1.2 \times 10^{-2}( \pm 3.2)$ \\
\hline
\end{tabular}

a $\%$ RSD based on three replicate analysis.

In practice, detection limits for the most selective electrodes are in the range of $10^{-5}-10^{-6} \mathrm{~mol} \mathrm{~L}^{-1}$. In this work the detection limit of the proposed membrane sensor was $6.3 \times 10^{-9} \mathrm{~mol} \mathrm{~L}^{-1}$ which was calculated by extrapolating the two segments of the calibration curve.

\section{Selectivity}

The potentiometric selectivity coefficients of the $\mathrm{Cu}^{2+}$ ion sensor were evaluated by the matched potential method (MPM) [46]. The calculated selectivity coefficient $\left(\mathrm{K}_{\mathrm{MPM}}\right)$ values are given in Table 4. A value of $\mathrm{K}_{\mathrm{MPM}}=1.0$ indicates equal response to primary and interfering ions. Further, the smaller the value of the selectivity coefficient, the higher is the selectivity of the sensor. It is seen from the table that the selectivity coefficient values are much smaller than 1.0 indicating that they exhibit sufficient selectivity towards $\mathrm{Cu}^{2+}$ over all the interfering ions studied.

\section{Lifetime}

The average lifetime of this sensors was investigated by monitoring the changes in sensor slope with time. The sensors were tested for 20 weeks, during which time the electrodes were used extensively (one hour per day). There is a slight gradual decrease in the slopes during 14 weeks (from 28.4 to $25.0 \mathrm{mV}$ per decade). After it, a significant change in slope is observed. The proposed sensors can be used for 14 weeks. It is well established that the loss of plasticizer, carrier, or ionic site from the polymeric film due to leaching into the sample is a primary reason for the limited lifetimes of the sensors $[47,48]$.

\section{Analytical Application}

Ion-selective electrodes tend to be; low in cost, simple to use, easily automated for rapid sampling, with low interferences from the matrix and can be applied to small volumes. These

Table 6. Comparison of the proposed $\mathrm{Cu}^{2+}$ ion electrode and the some previously reports.

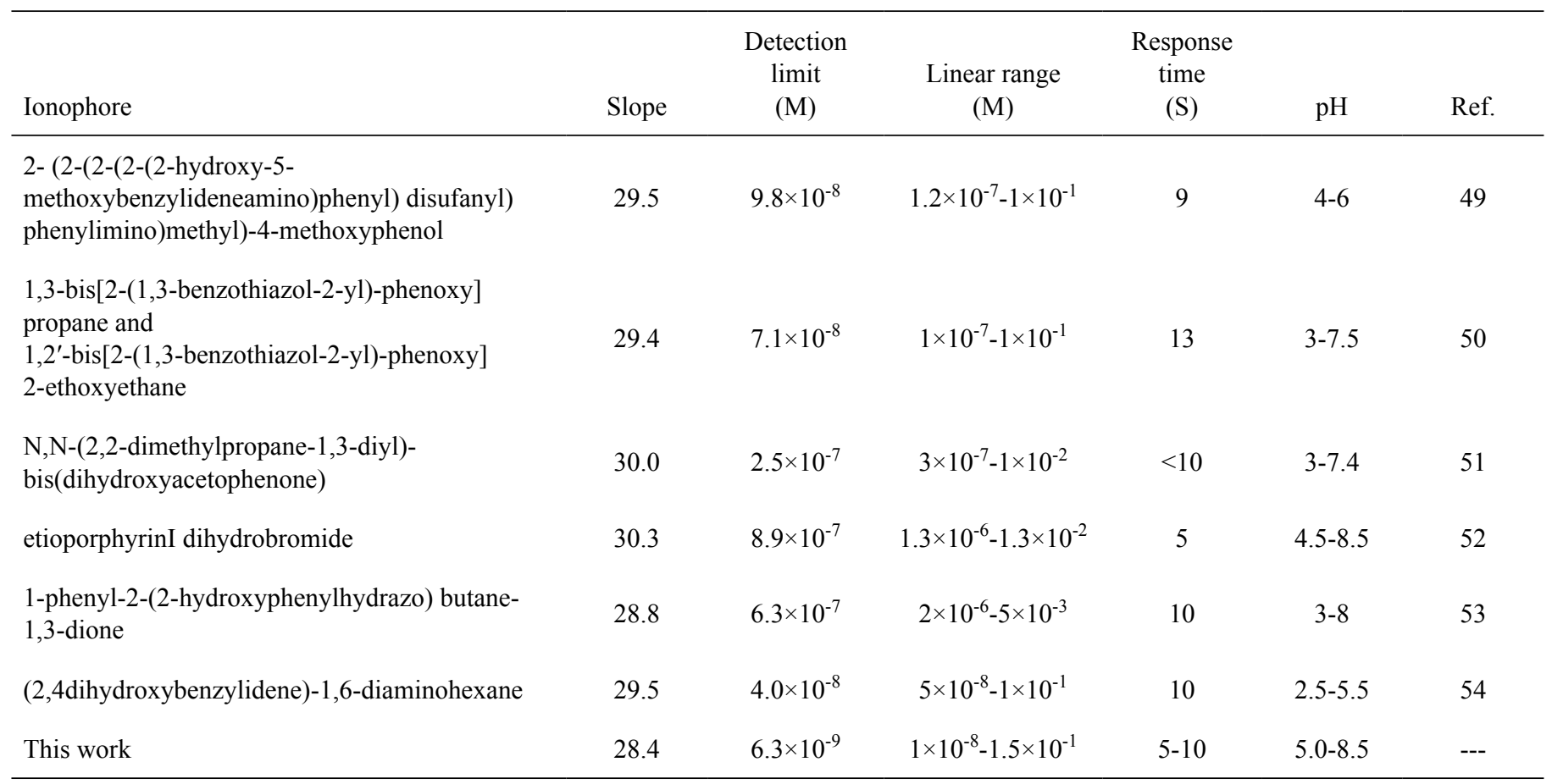


Leila Hajiaghababaei et al.

characteristics make them an ideal choice for environmental measurements.

The practical utility of the proposed membrane sensor was tested by its use as an indicator electrode for the titration of 25.0 $\mathrm{mL}$ of $1.0 \times 10^{-6} \mathrm{M}$ of $\mathrm{Cu}^{2+}$ solution with EDTA $1.0 \times 10^{-4} \mathrm{M}$. The resulting titration curve is shown in Fig. 8. As can be seen, the amount of $\mathrm{Cu}^{2+}$ ions in solution can be accurately determined with the electrode.

To assess the applicability of proposed electrode in real samples an attempt was made to determine $\mathrm{Cu}^{2+}$ ions in well water sample. The electrode was applied to the direct measurement of $\mathrm{Cu}^{2+}$ ion in Islamic Azad university of Shahre rey well water samples. All of the samples were filtered using a $0.45-\mu \mathrm{m}$ pore size membrane filter to remove suspended particulate matter. To the some sample solutions were added the $\mathrm{Cu}^{2+}$ ions and to some of solutions were added nothing. Potentials of the samples potentials were measured by direct potentiometry. As shown in Table 5, the proposed method could be applied successfully for the direct determination of $\mathrm{Cu}^{2+}$ ions in well water samples.

\section{Comparison of the proposed $\mathrm{Cu}^{2+}$ ion sensor and some of the best previously reports}

The Nernstian slope, linearity range, detection limit, $\mathrm{pH}$ range and response time of proposed $\mathrm{Cu}^{2+}$ ion sensor with some of the best previously reports are compared in Table 6. As is obvious, the results clearly indicate that the proposed sensor is superior to the previously reported ones in the detection limit and linearity range. In Nernstian slope and response time, proposed sensor is not superior but is closed to the best previously reports. It should be mentioned that it is found to perform satisfactorily over a relatively large range of $\mathrm{pH}$ values (5.0 to 8.5).

\section{Conclusions}

The results obtained from the above mentioned study revealed that 1-cyano-1-piperidino-2(N- piperidino methyl)-cyclohexane can be used as a selective sensing element in construction of a liquid membrane sensor for measurement of copper ions in the presence of considerable concentrations of common interfering ions. Applicable $\mathrm{pH}$ range, fast response time, low detection limit, and potentiometric selectivity coefficients of the proposed sensor make it a very good device used for the determinations of $\mathrm{Cu}^{2+}$ ions. Also, the various theoretical thermodynamic properties (such as enthalpy, entropy and Gibbs free energy) of the reaction complexation of some ions with sensing molecule were studied. The theoretical results according to experimental results were shown that the thermodynamic reactivity of complexation of copper ion with studied ligand is the best.

\section{Acknowledgments}

The author thanks the Islamic Azad University of Yadegar-e-Imam Khomeini (RAH) shahre-rey branch Research Council for the support of this work.

\section{References}

1. Morrison, G. M.; Handbook on Metal-Ligand Interactions in Biological Fields, In: Berthon G, Vol. 1, Ed., Marcel Dekker, New York, 1995, Chap.7A.

2. Linder, M. C.; Hazegh-Azam, M. Am. J. Clin. Nutr. 1996, 63, 797S-811S.

3. Ghazya, S. E.; El-Shazlya, R. M.; El-Shahawib, M. S; Al-Hazmia G. A. A.; El-Asmy, A. A. J. Iranian Chem. Soc. 2006, 3, 140-150.

4. Ganjali, M. R.; Hosseini, M.; Basiripour, F.; Javanbakht, M.; Hashemi, O. R.; Faal Rastegar, M., Shamsipur, M.; Buchanen, G. W. Anal. Chim.Acta 2002, 464, 181-186.

5. Faridbod, F.; Ganjali, M. R.; Pirali-Hamedan, M.; Norouzi, P. Int. J. Electrochem. Sci. 2010, 5, 1103-1112.

6. Ganjali, M. R.; Rafiei-Sarmazdeh, Z.; Poursaberi, T.; Shahtaheri, S. J.; Norouzi, P.; Int. J. Electrochem. Sci. 2012, 7, 1908-1916.

7. Mousavi, M. F.; Rahmani, A.; Golabi, S. M.; Shamsipur, M.; Sharghi, H. Talanta 2001, 55, 305-312.

8. Cesarino, I.; Marino, G.; Matos, J. R.; Cavalheiro, E. T. G. Ecl. Quím. São Paulo 2007, 32, 29-34.

9. Balaji, T.; Sasidharan, M.; Matsunaga, H. Anal. Bioanal. Chem. 2006, 384, 488-494.

10. Ensafi, A. A.; Meghdadi, S.; Allafchian, A. R. Sens. J. IEEE 2008, 8, 248-254.

11. Mashhadizadeh, M. H.; Sheikhshoaie, I. Talanta 2003, 60, 73-80.

12. Gupta, V. K.; Jain, S.; Khurana, U. Electroanalysis 1997, 9, 478-480.

13. Jain, A. K., Sondhi, S. M.; Sharma, V. K. Electroanalysis 2000, 12, 301-305.

14. Rofouei, M. K.; Mohammadi, M.; Gholivand, M. B. Mater. Sci. Eng. C 2009, 29, 2154-2159.

15. Ali Khan, A.; Paquiza, L. Desalination 2011, 272, 278.

16. Jumal, J.; Yamin, B. M.; Ahmad, M.; Heng, L. Y. APCBEE Procedia 2012, 3,116.

17. Ganjali, M. R.; Rezapour, M.; Pirali-Hamedani, M.; Rashedi, H. Int. J. Electrochem. Sci. 2015, 10, 6924-6934.

18. Fahmy, A.; Youssef, A.; Issa, Y. M.; Shehab, O. R.; Sherief, H. Int. J. Electrochem. Sci. 2015, 10, 4752-4769.

19. Bandi, K. R.; Singh, A. K.; Upadhyay, A. Mat. Sci. Engin. C 2014, 34, 149-153.

20. Sadeghi, S.; Eslahi, M.; Naseri, M. A.; Naeimi, H.; Sharghi; H.; Sameli, A. Electroanalysis 2003, 15, 1327-1333.

21. Singh, A. K.; Sahani, M. K.; Bandi K. R.; Jain, A.K. Mat. Sci. Eng. C 2014, 41, 206-216.

22. Ganjali, M. R.; Ghafarloo, A.; Faridbod, F.; Norouzi, P. Int. J. Electrochem. Sci. 2012, 7, 3706-3716.

23. Poursaberi, T.; Hajiaghababaei, L.; Yousefi, M.; Rouhani, S.; Shamsipur, M.; Kargar-Razi, M.; Moghimi, A.; Aghabazorg, H.; Ganjali, M. R. Electroanalysis 2001, 13, 1513-1517.

24. Ganjali, M. R.; Hajiaghababaei, L.; Taghvaei-Ganjali, S.; Modjallal, A.; Shamsipur, M.; Hosseini, M.; Javanbakht, M. Bull. Korean Chem. Soc. 2004, 25, 177-265.

25. Ganjali, M. R.; Shams, H.; Faridbod, F.; Hajiaghababaei, L.; Norouzi, P. Mat. Sci. Eng. C 2009, 29, 1380-1389.

26. Hajiaghababaei, L.; Abutalebyar, B.; Darvich, M. R.; Shekoftefar, S. Sensor Lett. 2013, 11, 2315-2321.

27. Hajiaghababaei, L.; Sharafi, A.; Suzangarzadeh, S.; Faridbod, F. Anal. Bioanal. Electrochem. 2013, 5, 481-493.

28. Hajiaghababaei, L.; Kazemi, S.; Badiei, A. R. Anal. Bioanal. Electrochem. 2012, 4, 246-261. 
29. Faridbod, F.; Khamseh-nejad, M.; Ganjali, M. R.; Norouzi, P.; Hajiaghababaei, L. Int. J. Electrochem. Sci. 2012, 7, 1917-1926.

30. Hajiaghababaei, L.; Shahvelayati, A. S.; Aghili, S. A. Anal. Bioanal. Electrochem. 2015, 7, 91-104.

31. List, B.; Po Jarliev, P.; Biller, W. T.; Martin, H. J. J. Am.Chem. Soc. 2002, 124, 827-833.

32. Halgren, T. A. J. Computational Chem. 1996, 17, 490-519.

33. Becke, A. D. J. Chem. Phys. 1993, 98, 5648-5652.

34. Becke, A. D. Phys. Rev. A 1998, 38, 3098-3100.

35. Lee, C.; Yang, W.; Parr, R. G. Phys. Rev. B 1988, 37, 785-789.

36. Deppmeier, B. J.; Driessen, A. J.; Hehre, T. S.; Hehre, W. J.; Johnson, J. A.; Klunzinger, P. E.; Leonard, J. M.; Pham, I. N.; Pietro, W. J.; Yu. J.; Irvine, C.A.; Spartan '10, Version 1.1.0, Wavefunction, Inc, 2011.

37. Bakker, E.; Bühlmann, P.; Pretsch, E. Chem. Rev. 1997, 97, 3083-3132.

38. Bakker, E.; Meyerhoff, M. E. Anal. Chim. Acta 2000, 416, 121-137.

39. Hamdan, A. J. Int. J. Eelctrochem. Sci. 2010, 5, 215-231.

40. Ganjali, M. R.; Norouzi, P.; Adib, M.; Ahmadalinezhad, A. Anal. Lett. 2006, 39, 1075- 1086.

41. Zamani, H. A.; Ganjali, M. R.; Norouzi, P.; Tadjarodi, A.; Shahsavani, E. Mater. Sci. Eng. C 2008, 28, 1489-1494.

42. Rosatzin, T.; Bakker, E.; Suzuki, K.; Simon, W. Anal. Chim. Acta 1993, 280, 197-207.
43. Telting-Diaz. M.; Bakker, E. Anal. Chem. 2001, 73, 5582.

44. Javanbakht, M.; Ganjali, M. R.; Eshghi, H.; Sharghi H.; Shamsipur, M. Electroanalysis 1999, 11, 81-84.

45. Ganjali, M. R.; Norouzi, P.; Rezapour, M. Am. Sci. Publisher (ASP) 2006, 8, 197-204.

46. Umezawa, Y.; Umezawa, K.; Sato, H. Pure. Appl. Chem. 1995, 67, 507-518.

47. Hosseini, M.; Ganjali, M. R.; Veismohammadi, B.; Faridbod, F.; Norouzi, P.; Dehghan Abkenar, S. Sens. Actuators B 2010, 147, 23-30.

48. Zamani, H. A.; Imani, A.; Arvinfar, A.; Rahimi, F.; Ganjali, M. R., Faridbod, F.; Meghdadi, S. Mater. Sci. Eng. C 2011, 31, 588-592.

49. Shokrollahi, A.; Abbaspour, A.; Ghaedi, M.; Naghashian Haghighi, A.; Kianfar, A. H.; Ranjbar, M. Talanta 2011, 84, 34-41.

50. Singh, A. K.; Sahani, M. K.; Bandi, K. R.; Jain, A. K. Mater. Sci. Eng. C 2014, 41, 206-216.

51. Ghanei-Motlagh, M.; Taher, M. A.; Saheb, V.; Fayazi M.; Sheikhshoaie, I. Electrochim. Acta 2011, 56, 5376-5385.

52. Issa, Y. M.; Ibrahim, H.; Shehab, O. R. J. Electroanal. Chem 2012, $666,11-18$.

53. Kopylovich, M. N.; Mahmudov, K.T.; Pombeiro, A. L. J. Hazard. Mater. 2011, 186, 1154-1162.

54. Ghaedi, M.; Khajehsharifi, H.; Montazerozohori, M.; Tavallali, H.; Tahmasebi, K.; Khodadoust, S. Mater. Sci. Eng. C 2012, 32, 674-679. 
